Gary Dowse and Paul Zimmet follow the fashion of designating this trait a "thrifty genotype" since "prospective studies in Pima Indians indicate that thrifty lower metabolic rates in humans may favour weight gain."' This is misleading: as others have found ${ }^{2}$ and Ravussin and Swinburn have emphasised, ${ }^{3}$ the absolute metabolic rate of obese Pima Indians is high, but those 15 subjects who subsequently gained more than $10 \mathrm{~kg}$ in four years had a lower metabolic rate adjusted for fat free mass, fat mass, age, and sex than the 111 subjects who did not gain $10 \mathrm{~kg}$ in four years. This is unlikely, however, to reflect a thrifty genotype, since at the end of the study those who had gained weight had a higher adjusted metabolic rate than those who had not. ${ }^{4}$ Analogy with genetically obese rodents is also misleading since, unlike obese humans, they have a reduced fat free mass, which explains their reduced metabolic rate.

The evidence does not support the hypothesis that people subject to famine have a tendency to obesity and non-insulin dependent diabetes because they have a low energy expenditure. The alternative hypothesis is that, during times when food is abundant, they have a high energy intake and thus store fat and become insulin insensitive. The difficulty in identifying a thrifty gene in humans may arise because it does not exists; we might have more success if we looked for a "stockpiling gene."

JOHN GARROW

Department of Human Nutrition

London EC1M 6BQ

1 Dowse G, Zimmet P. The thrifty genotype in non-insulin dependent diabetes. BMf 1993;306:532-3. (27 February.)

2 Garrow JS. Obesity and related diseases. Edinburgh: Churchill Livingstone, 1988.

3 Ravussin E, Swinburn BA. Pathophysiology of obesity. Lancet 1992;340:404-8.

4 Ravussin E, Lillioja S, Knowler WC, Christin L, Freymond D, Abbott WGH, et al. Reduced rate of energy expenditure as a risk factor for body-weight gain. $N$ Engl $f$ Med 1988;318: 467-72.

5 Garrow JS, Webster J. Are pre-obese people energy-thrifty? Lancet 1985;i:670-1.

EDrToR,-The only pessimistic note in Gary Dowse and Paul Zimmet's enthusiasm for the thrifty genotype hypothesis of non-insulin dependent diabetes occurs in their editorial's subtitle"the hypothesis survives." "There are many uncited reasons for thinking the concept to be in terminal decline.

Philosophically, the hypothesis is virtually impossible to falsify, as are many "polygenic" theories. Classical patterns of inheritance seem not to apply as expression of the genotype reaches well over $50 \%$ in most typically affected populations (for example, Pima Indians and Nauruans). More practically, are we to accept that only European populations have successfully adapted to whatever the post-reproductive selection factors are? This is a somewhat Eurocentric view. As Dowse and Zimmet concede, almost all non-European populations seem to carry the gene(s) at high frequency. Such diabetes has emerged in people of Indian subcontinent origin, in whom glucose intolerance affects over half of middle aged adults; in AfroCaribbeans, with adult rates of diabetes up to $30 \%{ }^{2}$; and in Latin Americans from Mexico and Venezuela, with mortality from diabetes in the later 1980s two or three times higher than that in the United States or Europe'; and rates are beginning to rise in Japan and South East Asia.

The whole assumption of a genetic rather than a familial basis for diabetes has recently been challenged by the twin registry study in Finland, which found 738 pairs of twins of whom at least one was diabetic, out of a national registry of over 13000 twins; 505 of these had non-insulin dependent diabetes. ${ }^{4}$ Contrary to concordance of over $90 \%$ when twins are ascertained through a diabetic proband, as in the King's College or American clinic series, pairwise concordance without glucose challenge was only $20 \%$ in monozygotic and $10 \%$ in dizygotic sets. That study is a major example of how such ascertainment bias from research in clinics can mislead a generation of clinicians and scientists.

The recent linkage of diabetes to mutations in the glucokinase gene affects only a fraction of the diabetic population, as has been found for other genes when properly sampled and tested controls were examined. Intergenerational effects through the maternal and early infant environment, which led to Hales and Barker's "thrifty phenotype" hypothesis," were not mentioned in the editorial This offers a direct challenge to the authors interpretation of their own data on the decline in incidence of the thrifty genotype in Nauru by suggesting that such decline is consistent with improving maternal environment over a generation and is not just explained by exhaustion of susceptible subjects.

These data indicate that the concept of the thrifty genotype may be nearing the end of its useful life. The suggestion that once the gene(s) have been found genetic screening could be offered to these populations also makes no sense in terms of public health. When basic health services are not yet available the costs of such screening would render it impractical and perhaps unethical.

Clinical Epidemiology Unit,

KENNEDY CRUICKSHANK

Diabetes Research Centre,

University of Manchester Medical School

Manchester M13 9PT

Dowse G, Zimmet $P$. The thrifty genotype in non-insulin dependent diabetes. BMF 1993;306:532-3. (27 February.)

2 Cruickshank JK, Cooper J, Burnett M, Macduff J, Drubra U. Ethnic differences in fasting C-peptide and insulin in relation to glucose tolerance and blood pressure. Lancet 1991;338: 842-7.

3 Pan American Health Organisation. Morrality statistics for selected causes of death in the Americas 1985-1989. Washington: PAHO, 1991.

4 Kaprio J, Tuomilehto J, Koshenvuo M, Romanov K, Reunanen $A$, Eriksson J, et al. Concordance for type 1 and type 2 diabetes mellitus in a population-based cohort of twins in Finland. Diabetologia 1992;35:1060-7.

5 Hales CN, Barker DJP. Type 2 (non-insulin dependent) diabetes: the "thrifty phenotype" hypothesis. Diabetologia 1992;35: 595-601.

\section{Persistent vegetative state}

EDrToR,-Clare Dyer states that the decision in the case of Tony Bland "may lead to legislation to define when and in what way doctors may intervene to end a patient's life."' Surely this should read "when and in what way doctors may cease to intervene to support a patient's life." This is not a semantic slant: it is crucial. Lord Browne-Wilkinson said that it was "difficult to find a moral answer" to the question "How can it be lawful to allow a patient to die slowly ... f from lack of food but unlawful to produce his immediate death by a lethal injection?" The suggested rephrasing could clarify the issue: lack of food is the cessation of intervention; a lethal injection is intervention.

All medical treatment is man's intervention with nature. Even when treatment is purely an attempt to support physiological responses to illness or to supply deficiencies-other than food and drink by mouth-it is still intervention. The scale of intervention has gathered pace over the centuries -sometimes with success, sometimes withoutbut it has now reached a stage when it seems to raise difficult ethical issues. Without recent advances in medical technology most, if not all, patients in intensive or terminal care would have died.

If, with a competent patient's informed consent, we agree to intervene in an illness and our intervention later proves futile we should, after explanation, be free to cease that intervention. When the patient is not competent, relatives and others must be involved. In both cases the medical responsibility should be shared with other colleagues.

DONALD RACTLIFFE

Bristol BS9 1DA

1 Dyer C. Law lords rule that Tony Bland does not create precedent. BMY 1993;306:413-4. (13 February.)

Author's REPLY,-I suppose, to be strictly correct, I should have said that the case of Tony Bland may lead to legislation to define "if, when, and in what way doctors may intervene to end a patient's life or cease to intervene to support life." I had in mind that the committee of peers under Lord Walton will be examining the whole issue of the criminal law and medical ethics-including cases of euthanasia such as that of Dr Nigel Coxand not just the narrow issue of patients, like Tony Bland, in a persistent vegetative state.

London NW1 7EG

CLARE DYER

\section{Diminishing delinquency in tortoises}

EDrTOR,-Minerva's report from the Institute of Psychiatry' shows that not only humans need protection from an excess of investigative zeal. Those of us who move in the world of Chelonia are keenly aware of the difficulties of palpating the gravid tortoise uterus (there is an extensive literature on the subject but I can't quite lay my hands on it at the moment). However, the depicted plain $x$ ray shows that you do not need to sustain the cost nor invoke the complexity of magnetic resonance imaging in order to show that a tortoise is pregnant. I say nothing of the lack of sensitivity

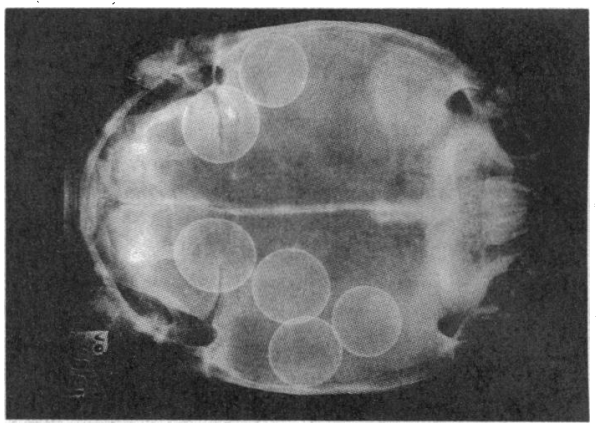

Plain $x$ ray of a female tortoise (Testudo graeca) showing the presence of at least seven eggs

(from psychiatrists, of all people) for the phobic anxieties widespread among the Testudo population. Presumably the poor animal in Minerva's photograph had just emerged from six months underground, only to find itself inserted into a dark narrow tube. Little wonder the rising tide of low slung graffiti on our greenhouse walls. I suppose Minerva's report above all shows what happens when even distinguished academics stray beyond the confines of their own expertise. Raymond Levy and Robert Howard should stick to treating depressed tortoises rather than pregnant ones.

London W1M 7AD

STEPHEN HERMAN

1 Minerva. BMF 1993;306:730. (13 March.)

\section{Correction}

\section{The future of FHSAs}

An editorial error occurred in this letter by Peter Von Eichstorff (20 February, p 520). Research ideas for his directory (requested in the third paragraph) should be less than 200 words long, not 20 words as stated. 